\title{
Immunocytochemical localization of insulin-immunoreactive cells in the pancreatic ducts of rats treated with trypsin inhibitor
}

\author{
C. V.Weaver ${ }^{1}$, R. L. Sorenson ${ }^{2}$ and H.C. Kaung ${ }^{2}$ \\ 'Research Laboratory, Department of Biology, Saint John's University, Collegeville, and \\ 2Department of Anatomy, University of Minnesota, School of Medicine, Minneapolis, Minnesota, USA
}

\begin{abstract}
Summary. It is well known that soybean trypsin inhibitor exerts trophic effects on the exocrine pancreas, resulting in the hypertrophy of acinar cells. Some evidence also exists for hyperplasia in acinar tissue, the ductal epithelium and islet tissue. Rats maintained for 3 weeks on an oral administration of soybean trypsin inhibitor $(200 \mathrm{mg} / 50 \mathrm{ml}$ drinking water) were compared with untreated animals. Significant changes were noted in treated animals $(p<0.01)$. Trypsin inhibitor-treated rats showed an increase in pancreatic weight $(2.33 \pm 0.46 \mathrm{~g})$. The volume ratio of acinar, islet and connective tissue as measured by the stereology point-count technique remained the same in both groups. Ductal tissue, however, exhibited an increase in volume ratio, $3.77 \pm 4.38 \%$ per $2714 \mu \mathrm{m}^{2}$ area of tissue, in trypsin inhibitor-treated animals. All tissue components showed an increase in the experimental animals: acinar $(125 \%)$, islet (144\%), ductal (325\%) and connective tissue
\end{abstract}

$(94 \%)$. Increased size of acinar cell nuclei, as measured by average cord length, $6.20 \pm 0.13 \mu \mathrm{m}$, and a decreased nuclear density of acinar cells, $28 \pm 4.74$ per $150 \mu^{2}$ area of tissue, indicated hypertrophic changes in these cells of the experimental animals. Using immunohistochemical localization and the point-count technique, a significant fraction of the total pancreatic volume in experimental animals was represented by ducts containing immunoreactive cells. The percent of volume ratio, $0.42 \pm 0.15 \%$ per $2714 \mu \mathrm{m}^{2}$ area of tissue, was calculated for ducts containing insulin-immunoreactive cells within their epithelium.

Key words: Soybean trypsin inhibitor, pancreatic duct cells, insulin immunoreactivity, pancreas, animal diabetes, experimental diabetes
The occurrence of insulin-containing cells within the pancreatic ductal epithelium has been reported under a variety of conditions in several species. Under normal conditions, post-natal pancreatic B-cell neogenesis via pancreatic ducts has been observed [1], but it is considered rare. In man, such occurrences have been noted under certain dietary regimens [2], in the pancreas of recent-onset Type 1 (insulin-dependent) diabetic patients [3], in sulphonylurea-treated diabetes [4], in cystic fibrosis of the pancreas [5], in pancreatic adaenomas [6], and in familial multiple endocrine adaenomatosis [7].

Under experimental conditions, ductular proliferation has been noted during regenerative phases in the islets of alloxan-treated animals [8-13], in steroid-treated $[14,15]$, and dextrose-injected animals [16], in subtotal pancreatectomies $[17,18]$, in normal and alloxan-diabetic rats subsequent to ductal ligation [19-21] and in tolbutamide-treated mice [22]. More recently, with immunohistochemical methods, immunoreactive insulin has been localized in the duct cells of neonatal rats treated with streptozotocin as they recovered from experimental diabetes [23], and in the duct cells of pancreas from MtTW15 mammosomatotropic tumourbearing rats [24].

In has been known for years that rats and chickens fed raw soybeans develop pancreatic enlargement and increased pancreatic enzyme secretion [25]. The effect of soybean feeding on the pancreas has been attributed to the heat-labile trypsin inhibitor contained in raw soybean. In a study by Yanatori and Fujita [26] comparing the pancreases of rats treated with raw soybean, trypsin inhibitor and subcutaneous injections of cholecystokinin-pancreozymin (CCK-PZ), it was shown that all three regimens produced hypertrophy of the exocrine pancreas. They observed that mitotic activity occurred not only in the acinar cells, but also in the ductal system, including the centroacinar cells and in the endocrine islets.

In the present experiments, we aimed to characterize duct cells immunohistochemically and to assess their quantitative change in rats treated with trypsin inhibitor. 
Table 1. Body weight, pancreatic weight and pancreatic/body weight ratios.

\begin{tabular}{lllll}
\hline & $\begin{array}{l}\text { Initial body weight } \\
(\mathrm{g})\end{array}$ & $\begin{array}{l}\text { Final body weight } \\
(\mathrm{g})\end{array}$ & $\begin{array}{l}\text { Pancreatic wet weight } \\
(\mathrm{g})\end{array}$ & $\begin{array}{l}\text { Pancreatic/body weight ratio } \\
\%\end{array}$ \\
\hline $\begin{array}{l}\text { Control rats } \\
(n=9)\end{array}$ & $147 \pm 3.05$ & $249 \pm 4.85$ & $1.10 \pm 0.12$ & $0.40 \pm 0.13$ \\
$\begin{array}{l}\text { Rats treated with trypsin inhibitor } \\
(n=9)\end{array}$ & $147 \pm 3.18$ & $243 \pm 6.08$ & $2.33 \pm 0.46^{\mathrm{a}}$ & $0.95 \pm 0.03$ \\
\end{tabular}

Results expressed as mean \pm SEM. ${ }^{a}$ Significantly different from control $(p<0.01)$

Table 2. Average point-count ratios (\%) of component tissues of the pancreas per $2714 \mu \mathrm{m}^{2}$ area of tissue

\begin{tabular}{llc}
\hline Tissue & $\begin{array}{l}\text { Rats treated with } \\
\text { trypsin inhibitor }(n=3)\end{array}$ & Control rats $(n=3)$ \\
\hline Acinar & $89.7 \pm 6.75$ & $90.5 \pm 7.60$ \\
Islet & $1.68 \pm 2.92$ & $1.58 \pm 4.14$ \\
Ductal & $3.77 \pm 4.38^{a}$ & $2.04 \pm 2.26$ \\
Connective & $3.52 \pm 3.36$ & $4.17 \pm 3.41$ \\
$\quad$ tissue septa & & \\
\hline
\end{tabular}

a Significantly different from control $(p<0.01)$

Table 3. Mean number of acinar nuclei contained in $150 \mu \mathrm{m}^{2}$ area and mean cord length measured on 200 nuclei

\begin{tabular}{lll}
\hline & Nuclear density & Nuclear size $(\mu \mathrm{m})$ \\
\hline $\begin{array}{l}\text { Rats treated with } \\
\text { trypsin inhibitor } \\
(n=9)\end{array}$ & $28 \pm 4.74^{\mathrm{a}}$ & $6.20 \pm 0.13$ \\
Control $(n=9)$ & $51.4 \pm 7.39$ & $5.67 \pm 0.08$
\end{tabular}

a Significantly different from control $(p<0.01)$

\section{Materials and methods}

\section{Animals}

Eighteen male Sprague-Dawley rats (weight approximately $150 \mathrm{~g}$ ) were divided equally into two groups. Group 1 was given, in lieu of ordinary water, a fresh solution of trypsin inhibitor ad libitum every $24 \mathrm{~h}$ and fed a normal rat chow diet. Group 2 received ordinary drinking water and a normal rat chow diet.

\section{Trypsin inhibitor}

Trypsin inhibitor $(200 \mathrm{mg}$ ) from raw soybean (Type II-S, Sigma Chemical Company, St. Louis, Mo, USA) was dissolved in $50 \mathrm{ml}$ of water with the $\mathrm{pH}$ adjusted to 7.0 with dilute $\mathrm{NaOH}$ as described by Yanatori and Fujita [26]. The inhibitory activity to the trypsin was commercially determined to be $1 \mathrm{mg} / 0.6 \mathrm{mg}$ of trypsin. A trypsin inhibitor assay, based on the rate of hydrolysis of the substrate o-toluenesuphonyl-L-arginine methyl ester (TAME) as measured by the increase in absorbancy at $247 \lambda$ [27], indicated that there was no loss in inhibitory activity of trypsin inhibitor during the $24-\mathrm{h}$ period.

\section{Tissue preparation}

After a period of 3 weeks, each rat was weighed, anaesthetized intraperitoneally (sodium pentobarbital, $0.1 \mathrm{ml} / 100 \mathrm{~g}$ body weight) and transcardially perfused with $0.9 \%$ saline. The pancreas of each animal was removed surgically, trimmed free of fat and lymph nodes, and the wet weight recorded. From the splenic region, a portion of tissue, approximately $1 \mathrm{~cm}^{2}$ in size, was removed. These were fixed for $12 \mathrm{~h}$ in Bouin's solution while agitated (40RPM) on a rotator platform (TekTator V, American Hospital Supply, Evanston, Ill, USA) and rinsed in
6 changes ( $2 \mathrm{~h}$ each) of $50 \%$ ethanol. They were dehydrated in graded ethanols, cleared in toluene, infiltrated in vacuo and embedded in Paraplast Plus (Monojet Scientific, St. Louis, Mo, USA). Each block of tissue was serially sectioned at $6 \mu \mathrm{m}$ on an AO-Spencer rotary microtome (Model 820: American Optical, Buffalo, NY, USA).

\section{Immunocytochemistry}

The sections of each block were serially mounted on gelatinized microscope slides, deparaffinized in xylene, rehydrated and stained immunocytochemically for insulin, using the unlabelled antibody enzyme technique of Sternberger et al. [28]. The primary antiserum (guinea pig, anti-bovine insulin serum: GP-Ab28, University of Minnesota, Minneapolis, Minn, USA) was diluted $(1: 500)$ with phosphate buffered saline $(0.2 \mathrm{M}, \mathrm{PBS})$ at $\mathrm{pH}$ of 7.2 , containing $1 \%$ normal sheep serum (Cappel Laboratories, Cochranville, $\mathrm{Pa}, \mathrm{USA}$ ). $50 \mu \mathrm{l}$ of the primary antibody were applied to each section and incubated in a humid chamber overnight at $4{ }^{\circ} \mathrm{C}$. The specificity of the antiserum was demonstrated by pre-absorption $(12 \mathrm{~h})$ of diluted primary antiserum with insulin $(100 \mu \mathrm{g} / \mathrm{ml})$ and substitution of normal serum for antiserum. The tissues were rinsed in PBS for 15 min subsequent to the incubation and the secondary antibody applied. The secondary antibody (sheep, anti-guinea pig IgG, Cappel) was diluted 1:250 with PBS. After the sections were incubated for $1 \mathrm{~h}$ at room temperature, they were rinsed in PBS for $15 \mathrm{~min}$ and $50 \mu \mathrm{l}$ of the peroxidase, anti-peroxidase (guinea pig PAP: Cappel) complex applied. These were incubated for an additional hour at room temperature and rinsed in PBS. The PAP chromagen was oxidized by placing the tissues in a solution of $3,3^{\prime}-$ diaminobenzidine tetrahydrochloride $(33 \mathrm{mg} / 100 \mathrm{ml}$ PBS, DAB: Grade II, Sigma) to which $0.05 \% \mathrm{H}_{2} \mathrm{O}_{2}$ was added until the reaction was complete as judged by microscopic inspection. The sections were washed in PBS, counterstained with Ehrlich's haematoxylin, dehydrated in graded ethanols, cleared in xylene and coverslipped with Histoclad (Clay Adams, Parsippany, NJ, USA).

\section{Quantitation and stereology}

Volume ratios. Each tissue component of the pancreatic sections, including acinar, ductal, islet and connective tissue septa, was quantitated using the stereology point-count technique to determine volume ratios. The determination of these volumes were based on the formulation as expressed by Delesse that the volume density of the various components within a sampling unit can be estimated on random sections by measuring the relative areas of their profiles [29]. Expressed as a formula, the area density $\left(A_{a}\right)$ of profiles on sections is an unbiased estimate of the volume density $\left(V_{v}\right)$ of the structures [30], or $A_{a}=V_{v}$. Furthermore, the number of test points contained within the parameter being measured $\left(P_{i}\right)$ and the total number of test points $\left(P_{i}\right)$ is also an estimate of $A_{a}[31]$, or:

$\frac{P_{i}}{P_{t}}=A_{a}=V_{v}$

The serially mounted and immunocytochemically-stained tissue of 3 animals from each group was used for this quantitative analysis. Using an Olympus BHS microscope (Olympus Optical Company, Tokyo, Japan), three micrographs were taken at random within the microscopic field of each slide throughout the first 20 sections sampled at every fiftecnth interval. This produced 60 micrographs per animal; 


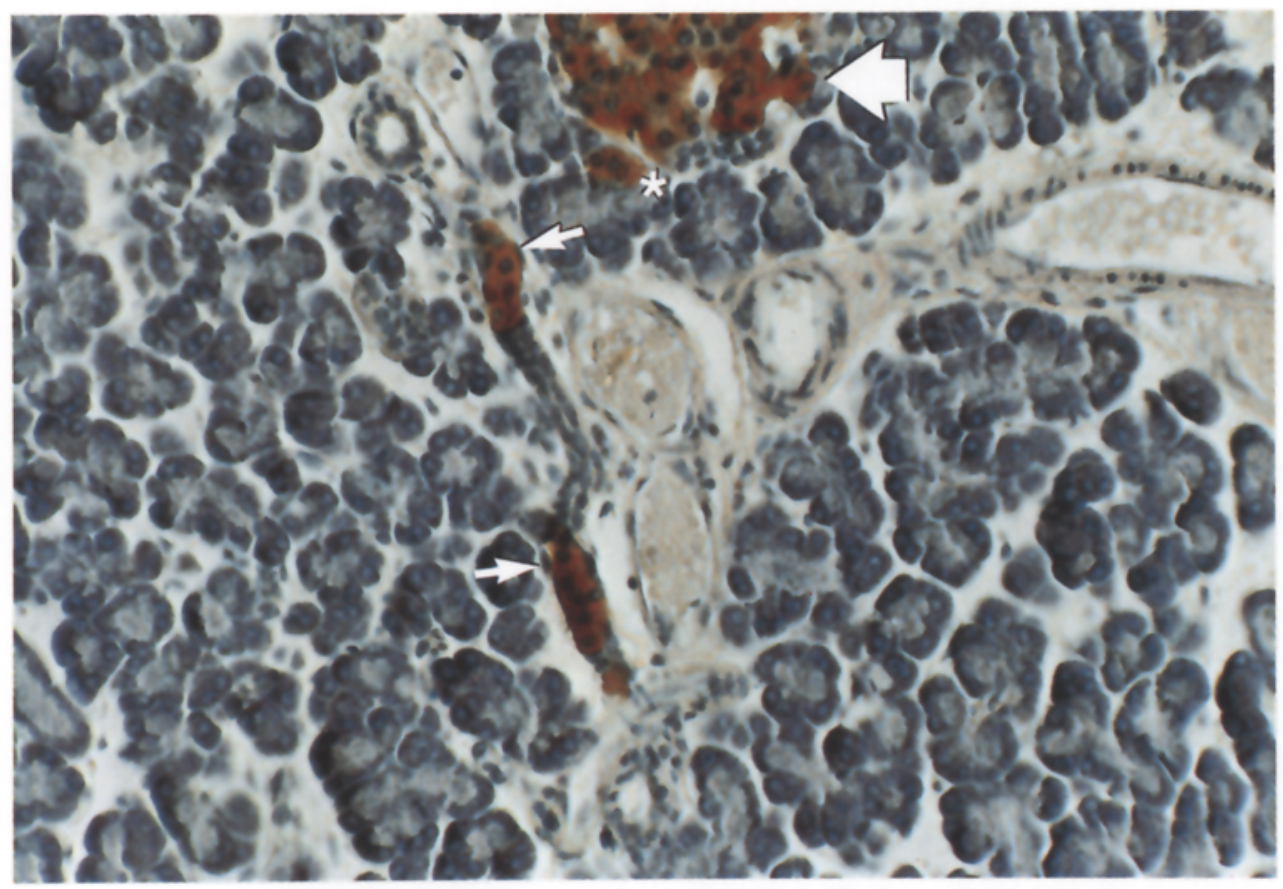

Fig. 1. A colour micrograph of pancreatic tissue from trypsin inhibitortreated rats. The insulin antibody stain is clearly distinguishable from non-immunoreactive tissue. Insulinimmunoreactive duct cells (small white arrows) are shown and can be compared to the B cell immunoreactive stain contained in an adjacent islet (large white arrow). A small group of insulin-immunoreactive cells, resembling acinar-B intermediate cells, are shown adjacent to the islet (asterisk). Magnification $\times 25$
360 in total, which were individually placed on a magnetized digitizer tablet of a Zeiss Videoplan Image analyzer (Cark Zeiss, New York, NY, USA). A point-count grid, measuring $160 \mathrm{~mm}^{2}$ and subdivided into 64 squares, was placed over each micrograph. Grid parameters and the magnification factor $(\times 60)$ were entered into the computer in preparation for the data acquisition sequence of the stereology program. The "hits" of component tissues within an area measuring $2714 \mu \mathrm{m}^{2}$ were recorded in each micrograph and their number automatically divided by the total number of possible hit points. The total values for each component tissue were averaged per group, compared statistically using the Student's t-test and expressed as mean percentage ratios. To assess the actual percentage of change in tissue components, the difference between the respective mean pancreatic weights of each group was multiplied by the percent of each tissue component and the gram weight increase divided by the control value.

Acinar quantitation. To measure further changes in acinar tissue, 5 light micrographs were taken of randomly selected microscopic fields of acinar tissue from serial slides prepared from each animal of both groups. The acinar cell nuclei, in a tissue area measuring $150 \mu \mathrm{m}^{2}$, were counted. The totals were averaged and group differences calculated by means of the Student's t-test as described above. The size of acinar cell nuclei, based on the measurement of the maximum cord length, of 200 randomly selected nuclei from each group, was assessed from this same group of micrographs. The totals were averaged and the comparison of means calculated as previously described.

\section{Duct quantitation}

The same micrographs used to determine volume ratio of ductal tissue were subsequently used to calculate the volume ratio of ducts in which insulin-immunoreactive cells were present within their epithelium. At the time the ductal points were calculated, their hit points were marked on each micrograph. The photographed area of the original microscope slide was located and the ducts which represented original hits on the micrograph identified. Each duct was re-examined through the microscope and those containing insulin-immunoreactive cells marked on the corresponding ducts of the micrograph. The point-count ratio was then re-calculated using the volume ratio of ducts with insulin-immunoreactive cells, their fraction values averaged and compared to control values. Preliminary attempts to count individual duct cells and to measure the length of ducts were found unreliable and inconsistent.

\section{Results}

After treatment with the oral trypsin inhibitor, there were no differences in the appearance or weight-gain of the treated rats compared with the controls. The final mean body weight of the treated rats, $249 \pm 4.58 \mathrm{~g}$, was similar to that of the controls, $243 \pm 6.08 \mathrm{~g}$ (Table 1 ). There was, however, a significant increase in pancreatic weight in the trypsin inhibitor-treated animals. The mean pancreatic weight in the treated animals was $2.33 \pm 0.46 \mathrm{~g}$ and the pancreatic/body weight ratio, $0.95 \pm 0.03 \%$ (Table 1 ).

The volume ratio of each component tissue of the pancreas remained consistent in both groups, except in the case of the ducts which was significantly higher in the treated rats, $3.77 \pm 4.38 \%$ (Table 2). All tissue components from the treated rats, however, showed an increase when the percent of change was calculated: 125\% (acinar), 144\% (islet), 325\% (ductal) and 94\% (connective tissue septa). The assessment of acinar nuclear density revealed a significant decrease in the treated rats. The mean number of nuclei in experimental animals was $28 \pm 4.74$ or $54.6 \%$ of the control value (Table 3 ). The mean size of acinar cell nuclei was significantly larger in the treated rats, $6.20 \pm 0.13$, or $9.3 \%$ larger than in control rats (Table 3 ). The point-count percent average of the volume ratio of ducts containing insulinimmunoreactive cells was significantly higher in the treated rats, $0.42 \pm 0.15 \%$, than in the untreated rats $0.07 \pm 0.01 \%(p<0.01)$.

The microscopic appearance of trypsin inhibitortreated tissue revealed a variety of ducts which contained insulin-immunoreactive cells. These cells, stained immunocytochemically with the oxidized dark brown chromagen of the PAP complex, were easily differentiated from the basophilic haematoxylin stain of adjacent duct cells and were identical to the pancreatic 


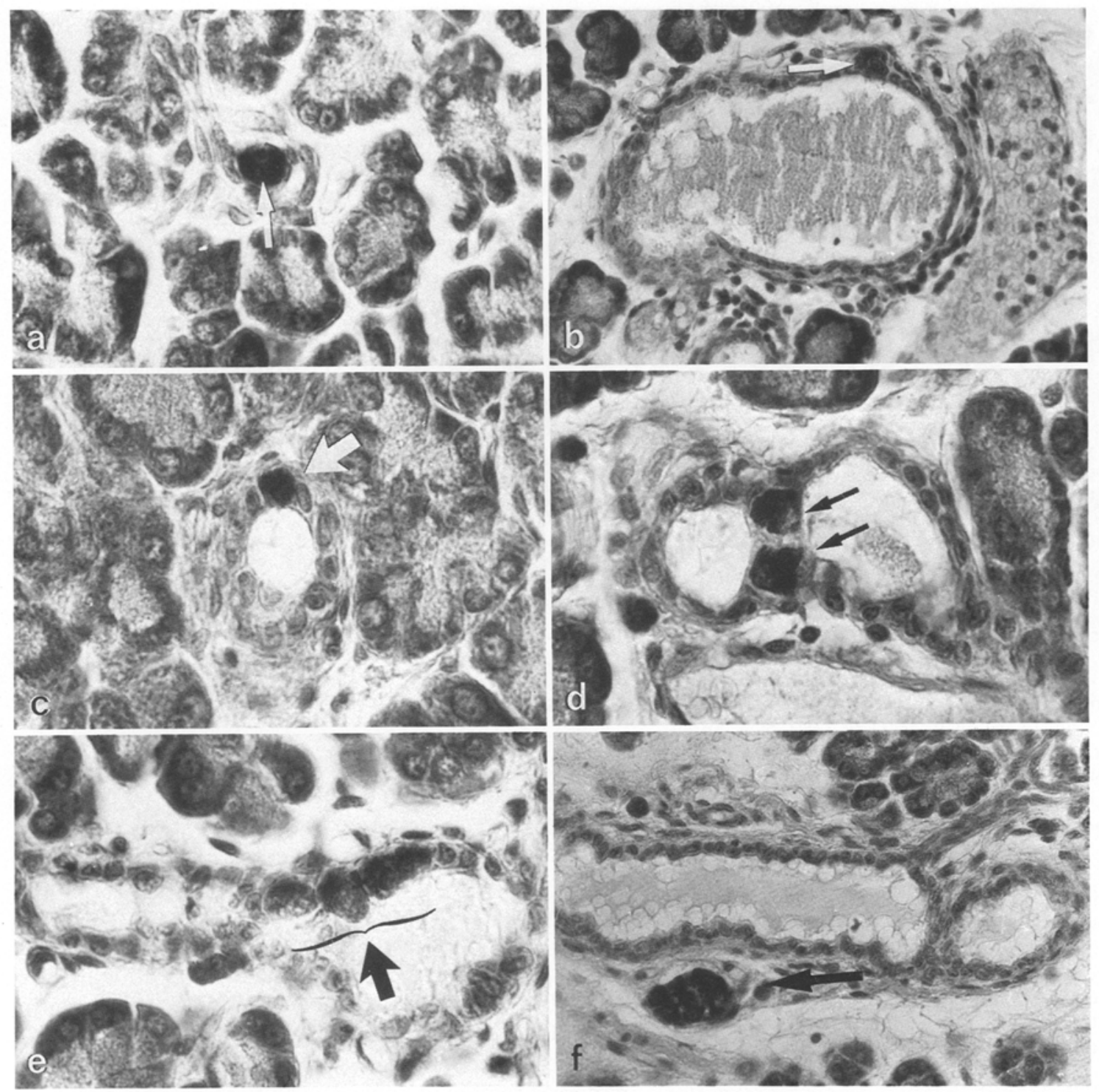

Fig. 2a-f. Insulin-immunoreactive cells localized immunocytochemically within the ductal epithelium of trypsin inhibitor-treated rats. a A single insulin-immunoreactive cell within the epithelium of a small intralobular duct (white arrow). b A single insulin-immunoreactive cell (white arrow) within the epithelium of a large interlobular duct. c A single insulin-immunoreactive cell (white arrow) within the epithelium of a small interlobular duct. d Two insulin-immunoreactive cells (black arrows) found within the epithelium of two adjacent interlobular ducts. e An aggregate of several insulin-immunoreactive cells (black arrows) within an interlobular duct. $f$ Small clusters of insulin-immunoreactive cells, as the one shown here (black arrow), were frequently encountered in close proximity with ducts. Magnification: $a, c-f, \times 50 ; b \times 60$

B cell stain of surrounding islets (Fig.1). These cells were found singly in both intralobular (Fig. 2a) and small and large interlobular ducts (Fig. $2 \mathrm{~b}-\mathrm{c}$ ), in discrete pairs (Fig. $2 \mathrm{~d}$ ), or as cellular aggregates within ductal epithelium (Figs. 1, 2e). Small clusters of insulinimmunoreactive cells were frequently found near large and small interlobular ducts (Fig. 2f). Large, irregularshaped islets could be found in the tissue of trypsin inhibitor-treated animals which were less apparent in tissue from untreated rats. Although not included in the quantitative analysis, small clusters of insulin-immunoreactive cells resembling putative acinar- $B$ intermediate cells observed by others in soybean-fed rats [32] were consistently encountered in tissue from treated rats, but oniy rarely in tissue from untreated rats (Fig. 1).

\section{Discussion}

In previous studies on soybean-fed and trypsin inhibitor-treated rats by Yanatori and Fujita [26] and Melmed et al. [32], duct cells were not characterized histologically and no immunohistochemical data was provided. Furthermore, no quantitation of these cells was available. In the present study, point-count quantitation supports the trophic effects of trypsin inhibitor on the pancreas and its component tissues. In addition, quantitation of nuclear density and size confirms hypertrophic changes in acini. Using immunohistochemical localization, significant numbers of ducts containing insulinimmunoreactive cells within their epithelium were found in trypsin inhibitor-treated animals. 
While there is no existing evidence to support the trophic effects of trypsin inhibitor on ductal tissue of the pancreas, the present study suggests that this may be possible. The exact mechanism of this trophic influence, however, is unclear. It may be mediated, at least in part, by the gastrointestinal hormone, cholecystokininpancreozymin (CCK-PZ), which is released from the mucosal epithelium of the gut and is thought to effect the changes in acinar tissue of soybean-fed and trypsin inhibitor-treated animals [25].

The occurrence of insulin-immunoreactive cells within ductal epithelium of trypsin inhibitor-treated animals remains unexplained. It may suggest a hypothetical B-cell cytotrophic response. While there was no change in the overall islet volume ratio, the percent of islet tissue increased in the treated rats. Further work is required to establish the significance of ductal cells exhibiting insulin immunoreactive.

Acknowledgements. This work was supported by a grant from the Vegas Foundation of Iowa. The microscopic system and Zeiss Videoplan Image analyzer were obtained by an NSF grant PCM-8409954. Grateful acknowledgement is made to Ms. J. Baker who supplied the primary antiserum.

\section{References}

1. Bunnag S (1966) Postnatal neogenesis of islets of Langerhans in the mouse. Diabetes 15: 480-491

2. Tejning $S$ (1947) Dietary factors and quantitative morphology of the islet of Langerhans. Acta Med Scand (Suppl) 198: 1-54

3. Gepts W (1965) Pathological anatomy of the pancreas in juvenile diabetes. Diabetes 14: 619-633

4. Bloodworth J (1963) Morphological changes associated with sulfonylurea therapy. Metabolism 12: 287-301

5. Walters M (1965) The ductular cells in pancreatic cyctic fibrosis. $J$ Pathol Bact 90: 45-52

6. Laidlaw G (1938) Nesidioblastoma, the islet tumor of the pancreas. Am J Pathol 14: 2124-2134

7. Vance J, Stoll E, Kitabachi A, Williams R, Wood F (1969) JAMA 207: $1679-1682$

8. Johnson D (1950) Alloxan administration in the guinea pig. A study of the regenerative phase in the islets of Langerhans. Endocrinology 47:393-398

9. House $\mathrm{E}$ (1958) A histological study of the pancreas, liver and kidney both during and after recovery from alloxan diabetes. Endocrinology 62: 189-200

10. Boquist L (1968) Alloxan administration in the Chinese hamster. I. Blood glucose variation, glucose tolerance, and light microscopal changes in pancreatic islets and other tissues. Virchows Arch Abt B Zellpathol 1: 157-168

11. Boquist L (1968) Alloxan administration in the Chinese hamster. II. Ultrastructural study of degeneration and subsequent regeneration of the pancreatic islet tissue. Arch Abt B Zellpath 1: 169-181

12. Boquist $L(1968)$ Cilia in normal and regenerating islet tissue. Zellforsch $89: 519-532$

13. Patent G, Alfert M (1967) Histological changes in the pancreatic islets of alloxan-treated mice, with comments on B-cell regeneration. Acta Anat 66: 504-519

14. Lazarus $S$ (1959) Pancreatic adaptation to diabetogenic hormones. Arch Pathol 67:456-467
15. Hausberger F, Ramsay A (1953) Steroid diabetes in guinea pigs. Effects of cortisone administration on blood and urinary glucose, nitrogen excretion, fat deposition, and the islets of Langerhans. Endocrinology $53: 423-435$

16. Woerner C (1938) Studies of the islands of Langerhans after continuous intravenous injection of dextrose. Anat Rec 71: 33-57

17. Marx M, Schmidt W, Goberna R (1970) Elektronenmikroskopische Untersuchungen zur Inselregeneration im Rattenpankreas nach subtotaler Pankreatektomie. Z Zellforsch Mikrosk Anat 110: $569-587$

18. Friedman N, Marble A (1941) Island hyperplasia in the partially depancreatized rat. Endocrinology 29: 577-582

19. Zweens J, Bouman P (1967) Neoformation of insulin-producing islets following ligation of the pancreatic ducts in normal and alloxan-diabetic rats. Acta Physiol Pharmacol Neerl 14: 529-531

20. Edstrom C (1973) Course of alloxan diabetes in duct-ligated rats. A functional and morphologic study. Acta Path Microbiol Scand Sect A 81: 21-36

21. Edstrom C, Boquist L (1973) Alloxan diabetes in duct-ligated rats. Light and electron microscopic findings. Acta Path Microbiol Scand Sect A 81: 21, 36

22. Bunnag S, Warner N, Bunnag S (1966) Effects of tolbutamide on postnatal neogenesis of the islet of Langerhans in mouse. Diabetes 15: 597-603

23. Cantenys D, Portha B, Dutrillaux M, Hollande E, Roze C, Picon L (1981) Histogenesis of the endocrine pancreas in newborn rats after destruction by streptozotocin: an immunocytochemical study. Virchows Arch (Cell Pathol) 35: 109-122

24. Parson J, Hartfel M, Hegre O, McEvoy R (1983) Effects of MtTW15 mammosomatotropic tumors on pancreatic islet hormones. Diabetes 32: 67-74

25. Solomon TE (1981) Regulation of exocrine pancreatic cell proliferation and enzyme synthesis. In: Johnson LR (ed) Physiology of the gastrointestinal tract, vol2. Raven Press, New York, pp 873-892

26. Yanatori Y, Fujita T (1976) Hypertrophy and hyperplasia in the endocrine and exocrine pancreas of rats fed soybean trypsin inhibitor or repeatedly injected with pancreozymin. Arch Histol Jpn 39: $67-78$

27. Hummel B (1970) A modified spectrophotometric determination of chymotrypsin, trypsin and thrombin. Can J Biochem 9: 156

28. Sternberger L, Hardy P, Cuculis J, Meyer H (1980) The unlabeled antibody method of immunohistochemistry. Preparation and properties of soluble antigen-antibody complex (horseradish peroxidase-antihorseradish peroxidase) and its use in identification of spirochetes. J Histochem Cytochem 23: 315-333

29. Delesse A (1847) Procède méchanique pour determiner la composition des roches (extrait). CR Acad Sci (Paris) 25: 544-545

30. Bolender RP, Weibel ER (1973) A morphometric study of the removal of phenobarbital-induced membranes from hepatocytes after cessation of treatment. J Cell Biol 56: 746-754

31. Chalkley HW (1943) Method for the quantitative morphologic analysis of tissues. J Natl Cancer Inst 4:47-53

32. Melmed R, Turner R, Holt S (1973) Intermediate cells of the pancreas. II. The effects of dietary soybean trypsin inhibitor on acinar-B cell structure and function in the rat. J Cell Sci 13:279-295

Received: 3 August 1984

and in revised form: 19 June 1985

C. V. Weaver

Research Laboratory

Saint John's University

Collegeville, MN 56321

USA 